\title{
EFFECT OF HYDRO-PRIMING AND SALINITY STRESS ON GERMINATION INDICES OF NIGER (GUIZOTIA ABYSSINICA CASS.)
}

\author{
Afsaneh Badalzadeh ${ }^{1}$, Abolrazagh Danesh Shahraki² \\ ${ }^{1}$ Biotechnology Research Institute, Shahrekord University, P. O. Box 88186/34141, Shahrekord, Iran \\ ${ }^{2}$ Department of Agronomy, Shahrekord University, P. O. Box 88186/34141, Shahrekord, Iran
}

Link to this article: https://doi.org/10.11118/actaun.2021.046

Received: 3. 11. 2020, Accepted: 28. 6. 2021

To cite this article: BADALZADEH AFSANEH, DANESH SHAHRAKI ABOLRAZAGH. 2021. Effect of Hydro-priming and Salinity Stress on Germination Indices of Niger (Guizotia abyssinica Cass.). Acta Universitatis Agriculturae et Silviculturae Mendelianae Brunensis, 69(4): 511-518.

\begin{abstract}
In order to evaluate the effect of hydropriming and Salinity stress on germination indices of Niger, a factorial experiment was conducted in a randomized complete block design with four replications at seed research laboratory of Shahrekord University. Salinity treatments were applied at five levels $(0,25,50,100$ and $150 \mathrm{mM} \mathrm{NaCl})$. Hydropriming treatments were applied at two levels (control and 6-hour hydropriming with distilled water). Results showed that the effects of hydropriming with distilled water and salinity stress on all the studied traits were significant at $\mathrm{P} \leq 0.01$. However, the interaction effects of hydropriming and salinity stress were only significant for the mean germination time, root and shoot lengths, and the allometric coefficient. The hydro prime of Niger seed resulted in the germination percentage, speed and mean germination time to be decreased significantly compared to the control treatment. The germination percentage, the time to 50\% of germination, mean germination time and germination energy decreased significantly with the increasing salinity level. Hydropriming positively affected the allometric coefficient and improved its value compared to the control (non-hydropriming conditions).
\end{abstract}

Keywords: germination rate, mean germination time, oil plants, seed enhancement treatments, water and soil quality

\section{INTRODUCTION}

In recent years, a new oil plant named Niger seed was imported to Iran as a multi-purpose and nonnative plant in order to supply bird foods. The oil plant Niger seed (Guizotia abyssinica Cass) is from Asteraceae family, a dicot annual herb. Ethiopia and India are the two major Niger seed producing countries (Bhatnagar and Krishna, 2013). Niger seeds contain 38 to 43\% edible oil and 20\% protein (Dalei et al., 2014). Niger seed oil contains large amounts of omega-6 PUFA (63-75\%) (Bhatnagar and Krishna, 2013).

Salinity is one of the major abiotic stresses which have adverse effect on plant growth and yield worldwide (Naik and Varadahalli, 2020). It has been predicted that more than $50 \%$ of the arable land would be salinized by the year 2050 (Pooja and Rajesh, 2015). For purposes of definition, saline soils are those which have an electrical conductivity (EC) of the saturation extract (ECe) in the root zone of more than $4 \mathrm{dS} / \mathrm{m}(\sim 40 \mathrm{mM} \mathrm{NaCl})$ at $25^{\circ} \mathrm{C}$ (Naik and Devaraj, 2016). Most reports indicate that salinity reduces plants growth and biomass production. Salinity affects seed germination by restricting water absorption, reducing breakdown of seed storage materials, and disturbing the synthesis of stored proteins. Several studies have investigated the effect of salinity stress on germination and seedling growth of oil plants. The inhibitory effects of salinity stress have been reported on the seed germination indices of Niger (Patil et al., 2010). 
Different seed priming strategies have been suggested to improve seed germination, uniform emergence and strong plant establishment. One of these methods is seed hydropriming. The seed hydropriming could improve seed germination rate, and uniform seed emergence, the stand establishment, seedling vigor, and productivity of field crops under optimal and suboptimal conditions (Hasanuzzaman and Fotopoulos, 2019). Faroog et al. (2010) reported an increase in the germination rate and percentage of sunflower seeds by hydropriming treatment. They argued that hydropriming increased the activity of amylase enzymes and the seed storage compounds break down, which resulted in more vigorous plant growth. Nematollahi et al. (2009) studied the effect of hydropriming on Cumin (Cuminum cyminum L.) seed germination and showed that hydropriming treatment was able to increase germination rate Nawaz et al. (2016) also reported the similar results with wheat.

The present study was carried out in order to apply the seed hydropriming to investigate the effects of seed hydropriming on germination indices and early growth of Niger under salinity stress condition.

\section{MATERIALS AND METHODS}

This study was performed in seed research laboratory of Shahrekord University in 2018. The experiment was conducted in a factorial arrangement in a randomized complete block design with four replicates. Salinity treatments were arranged at five levels (0, 25, 50, 100 and $150 \mathrm{mM})$. Hydropriming treatments were applied at two levels (control and 6-hour hydropriming with distilled water). The seeds were obtained from Pakan Bazr Co., Isfahan, Iran. The seeds were first rinsed under running water for $5 \mathrm{~min}$. Then, they were washed with distilled water for three times. The seeds were, disinfected for $10 \mathrm{~s}$ with $70 \%(\mathrm{v} / \mathrm{v})$ ethanol and then soaked for $10 \mathrm{~min}$ in sodium hypochlorite solution $2 \%$. In each Petri dish, 50 seeds were cultured and $3 \mathrm{ml}$ of sodium chloride solution was added according to the experimental treatments. The petri dishes were sealed with cellophane film and incubated at $20^{\circ} \mathrm{C}$ to $30^{\circ} \mathrm{C}$ under dark/light condition (16:8 h) (Ellis et al., 1985). The germination count was performed daily at the same time from the first day. On the seventh day, seedlings were measured for the length of root and shoot and shoot:root ratio were calculated as an allometric coefficient (Patil et al., 2010). Seed vigor obtained from multiplying final germination percentage with seedling length (Damalas et al., 2019). Germination percentage (GP), germination rate (GR), Mean germination time (MGT), mean daily germination (MDG), times to reach to $50 \%$ germination $\left(\mathrm{T}_{50}\right)$ and germination energy (GE) were determined using the following equations (1-6):
$G P=\frac{N_{g}}{N_{t}}$,

where $N_{g}$ is the number of germinated seeds and $N_{t}$ is the total number of seeds (Damalas et al., 2019).

$G R=\sum_{i=1}^{n} \frac{S_{i}}{D_{i}}$,

$M G T=\frac{\sum_{i=1}^{n}\left(S_{i} D_{i}\right)}{\sum_{i=1}^{n} D_{i}}$,

where $S_{i}$ is germinated seeds per counting, $D_{i}$ represents seed numbers until $n^{\text {th }}$ day and $n$ is number of the counting (Aflaki et al., 2017).

$M D G=\frac{G P}{d}$,

where $G P$ is germination percentage, and $d$ represents number of days (Aflaki et al., 2017).

$T_{50}=t_{i}+\frac{\left(\frac{N}{2}-n_{i}\right)\left(t_{j}-t_{i}\right)}{n_{j}-n_{i}}$,

where $N$ is the final number of germination and $n_{i}, n_{j}$ cumulative number of seeds germinated by adjacent counts at times $t_{i}$ and $t_{j}$ when $n_{i}<N / 2<n_{j}$ (Farooq et al., 2006).

$G E=\frac{n_{i}}{N} \times 100$,

where, $n$ is number of germinated seeds during $i$ day, $i$ is the number of days from the beginning of germination and $N$ is the total number of seeds tested. Energy of germination (GE) recorded on the $3^{\text {rd }}$ day after planting, is the percentage of germinating seeds 3 days after planting relative to the total number of seeds tested (Farooq et al., 2006).

Analysis of variance was carried out in order to compare the effects of hydropriming and salt stress on germination indices of Niger. The data were analyzed using one-way ANOVA by SAS software (version 9, SAS Institute Inc., NC). Mean comparisons were accomplished using the least significant difference (LSD) test $(\mathrm{P}<0.05)$.

\section{RESULTS AND DISCUSSION}

The effects of hydropriming and salinity stress on all the studied traits were significant at $\mathrm{P} \leq 0.01$. However, the interaction effects of hydropriming and salinity stress was significant $(P \leq 0.01)$ only for the mean germination time, root and shoot lengths, and the allometric coefficient (Tab. I).

\section{Percentage, Rate and Mean Germination Time}

The results showed that the hydro prime of Niger seed significantly reduced germination percentage, 


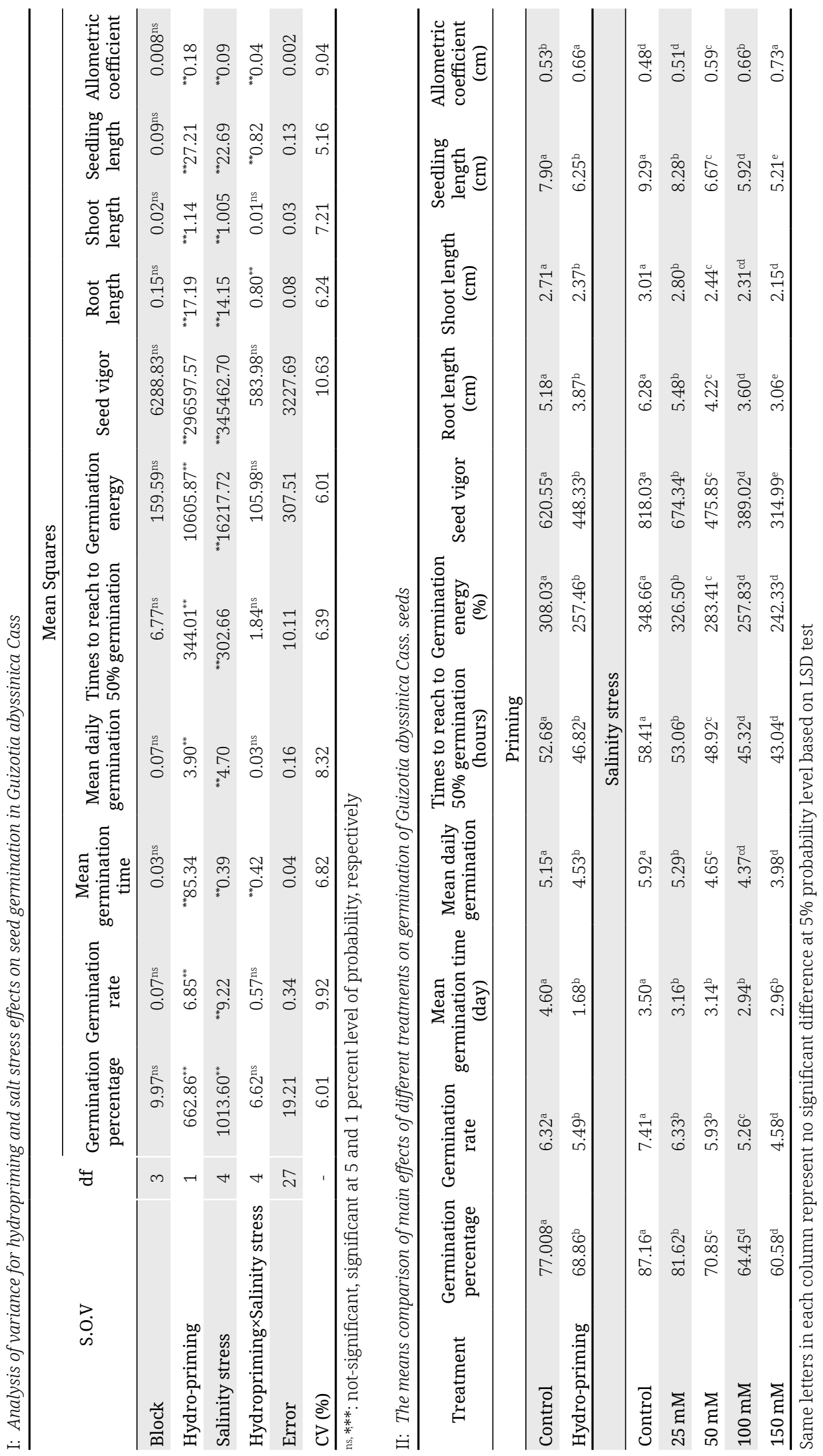


rate and mean germination time compared to the control, so that the highest and lowest levels of these features belonged to the control and hydropriming treatments, respectively (Tab. II). Bijanzadeh et al. (2010) obtained similar results when studying the influence of seed priming techniques on germination and emergence of rapeseed (Brassica napus L.). They suggested that although the seed hydropriming led to increasing the germination percentage, establishment, and drought resistance, seed germination percentage was higher under the control. In addition, they suggested that after the hydro primed seeds accessed to water during the germination, these seeds had more time to absorb water in order to restart metabolic processes for germination. Yuan-Yuan et al. (2010) indicated that hydropriming of rice seeds could significantly increase germination percentage and speed germination.

The means comparison of different levels of salinity stress showed that increasing the salinity stress level resulted in decreasing the germination rate. The lowest germination percentage and rate at salinity level $150 \mathrm{mM}$ were observed with 30.49\% and $38.19 \%$ decrease compared to the control, respectively. The highest mean germination time was obtained in the control treatment and the lowest one was obtained in the treatment of $100 \mathrm{mM}$ salinity (Tab. II). The results obtained in this study are consistent with those by Tuncturk et al. (2011) with rapeseed. Patil et al. (2010) also reported that the highest salinity levels decreased the germination percentage in rapeseed. They suggested that the reason was related to the increased salinity levels and its effects on cell division and plant metabolism. They also found that the reduced seed germination percentage occurred probably due to decreased water potential gradient between the seeds and the surrounding environment, and consequently disturbing the synthesis of the necessary enzymes for germination.

The means comparison of the interaction of hydropriming and salinity stress on germination time showed that the non-hydropriming treatment made the levels of this feature to be decreased significantly. The highest germination time values were observed in the non-hydropriming conditions treatment with control salinity level, and the lowest level was associated with hydropriming treatment at salinity level of $25 \mathrm{mM}$ (Fig. 1). The results found in this study are consistent with those by Tuncturk et al. (2011) with rapeseed.

\section{Mean Daily Germination, Times to Reach to $50 \%$ Germination and Germination Energy}

The hydro prime of Niger seed significantly reduced the germination percentage per day, the time to $50 \%$ of germination, mean germination time and germination energy compared to the control group. The highest and lowest levels of these features were related to the control and hydropriming treatments (Tab. II). The results found in the present work are consistent with Farooq et al. (2010) finding on hydropriming of sesame seeds. They observed the highest levels of these features in control treatment. However, Nematollahi et al. (2009) indicated that the hydro prime of rapeseed and fennel seeds increased the germination percentage, the time to $50 \%$ of germination, mean germination time and germination energy.

The germination percentage, the time to $50 \%$ of germination, mean germination time and germination energy significantly decreased by increasing salinity stress level. The lowest levels of these treats were observed with 32.77, 26.31, 30.49 and 30.49\% compared to the control treatment at salinity level of 150 mM, respectively (Tab. II). Demir Kaya et al. (2006) indicated that salinity stress resulted in reduction in both the percentage of germination and average germination time in sunflower. They noticed that the reduced germination percentage and the time taken for reaching to 50\% of germination was due to high and toxic concentration of soluble cations and anions in the medium under which the water potential is highly reduced. Therefore, the plant was

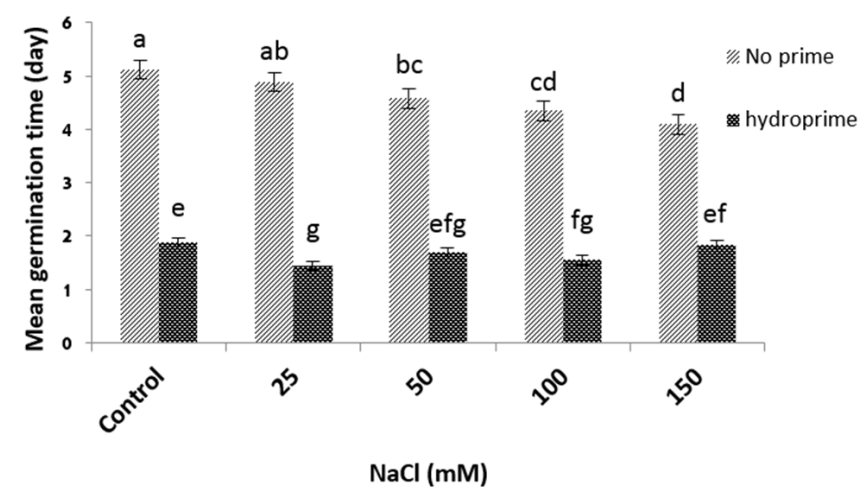

1: Interaction effects of hydro-priming and salinity stress on mean germination time

Means having the same letter are not different at 5\% level based on LSD test 
not able to absorb water, and consequently, it dies. Researchers also suggested that the reduced level of germination energy was caused by the activation of mechanisms related to the salinity tolerance at the cell and tissue levels.

\section{Seed Vigor}

The hydropriming of Niger seed decreased the seed vigor significantly compared to the control. The highest and lowest values were related to the control and hydropriming treatment, respectively (Tab. II). Ghasemi-Golazani et al. (2010) showed that hydropriming of Pinto Bean seeds (Phaseolus vulgaris L.) resulted in the seed vigor to be increased significantly. The comparison of the mean different levels of salinity stress showed that gradual increase of salinity stress decreased the seeds vigor. The lowest seed vigor value was observed at salinity level of $150 \mathrm{mM}$ with $61.49 \%$ reduction compared to the control (Tab. II).

The results are consistent with those by Nazarbeygi et al. (2011) with Canola. They suggested that the sodium chloride treatments at all salinity levels decreased the seed vigor. Seed vigor is an indication of seed germination percentage and seedling length. Therefore, any reduction in seed vigor could be due to negative effects of environmental stresses on these parameters.

\section{Root, Shoot and Seedling Lengths}

The hydropriming of Niger seeds resulted in the root, shoot and seedling lengths to be significantly decreased compared to the control, so that the highest and lowest levels of these features were observed in the control and hydropriming treatment, respectively (Tab. II). Bijanzadeh et al. (2010) indicated that hydropriming of rapeseed (Brassica napus L.) increased the root and shoot lengths. The means comparison of different levels of salinity stress showed that the root, shoot and seedling lengths were significantly decreased by increasing the salinity level.
The lowest root, shoot, and seedling length were observed at $150 \mathrm{mM}$ salinity level by $51.27,28.57$ and 43.91\% decrease compared to the control treatment, respectively (Tab. II). The results are consistent with those by Patil et al. (2010) and Stassinos et al. (2021) with Niger and rapeseed, respectively. The root length was reported to be the most sensitive part of the plant to the salinity stress, when studying its effect on the root and shoot lengths. The function of cytokinin hormone is blocked in the root under the salinity stress. Therefore, the root length is a suitable criterion in order to measure the tolerance to salinity stress in different plants. Moreover, the reason of decreased seedling growth in response to the increased salinity stress was stated due to the osmotic effects caused by the lack of water, the toxic effects of ions, and the lack of balanced necessary food absorption, which might negatively affect the plant metabolism (Cramer et al., 1994). It seems that the division and development of the cells requires the transmission of respiratory process products like soluble sugars from the seed storage sites to the growth areas during the budding and in the early growth of seedling. Salinity can reduce the shoot length due to restriction of the hydrolysis of seed food storage, and inhibition of their transmission into the embryonic axis (Dakhil and Denden, 2010).

The mean comparison of interactions of hydropriming treatment and salinity stress on the root length indicated that non-hydropriming treatment significantly decreased the root length, while there was no significant difference between the two control treatments at salinity levels of 100 and $150 \mathrm{mM}$. On the other hand, the hydropriming treatment was able to significantly reduce the root length which resulted in the highest reduction at $150 \mathrm{mM}$ salinity (Fig. 2). Moreover, the mean interactions of hydropriming and salinity stress on seedling length showed that non-hydropriming treatment significantly reduced the seedling length. On the other hand, this significant decrease

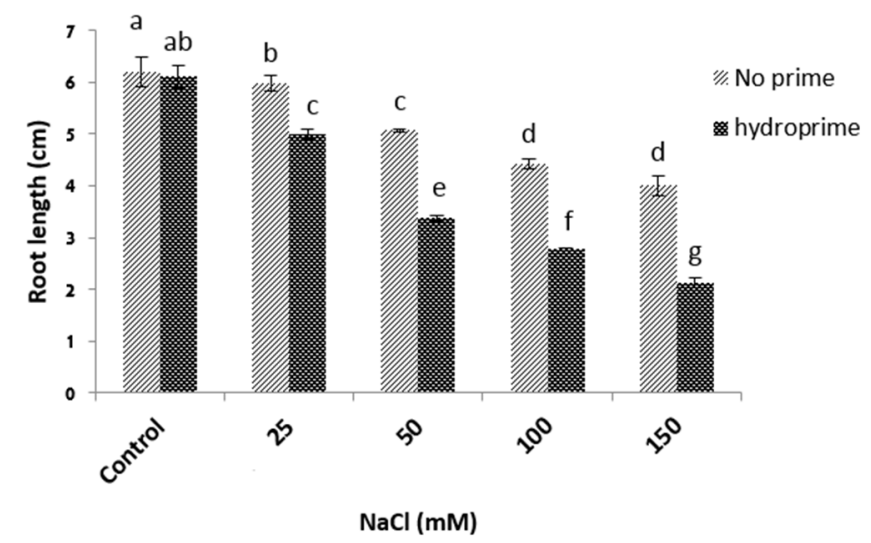

2: Interaction effects of priming and salinity stress on Root length Means having the same letter are not different at 5\% level based on LSD test 


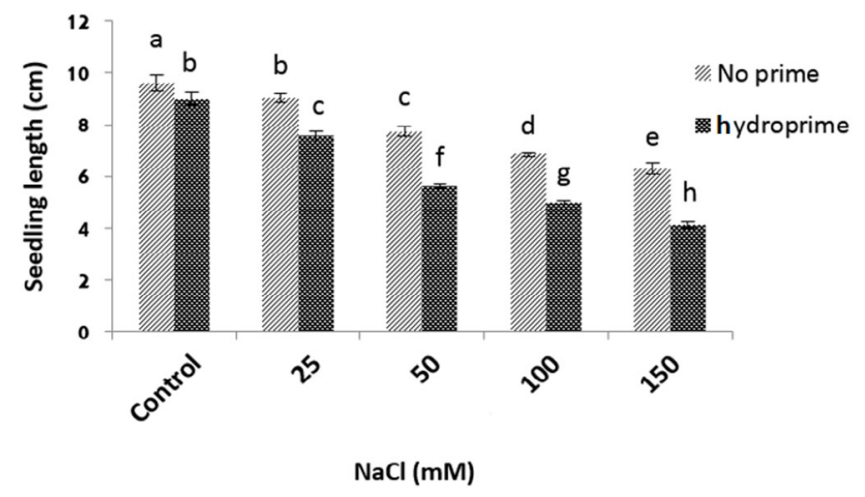

3: Interaction effects of priming and salinity stress on Seedling length Means having the same letter are not different at 5\% level based on LSD test

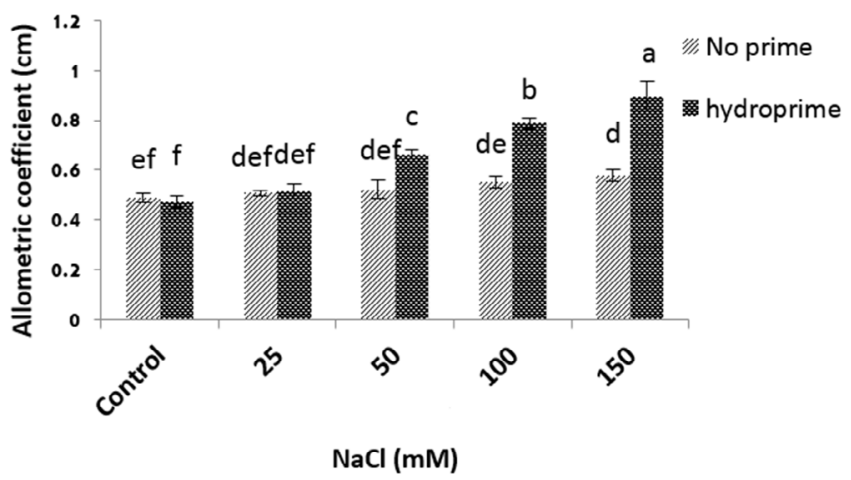

4: Interaction effects of priming and salinity stress on Allometric coefficient

Means having the same letter are not different at 5\% level based on LSD test

was observed in hydropriming treatment, too. The lowest seedling length value occurred under hydropriming treatment at $150 \mathrm{mM}$ salinity level (Fig. 3).

\section{Allometric Coefficient (Shoot: Root Ratio)}

The hydropriming of Niger seed increased the allometric coefficient compared to the control treatment. The highest and lowest values were associated with hydropriming treatment and the control (Tab. II). The results are consistent with those by Saglam et al. (2010) on Lentil (Lens culinaris Medik). They stated that the reduced length of shoot resulted in increasing allometric coefficient value under hydropriming treatment. However, Nematollahi et al. (2009) showed that the hydropriming of seed of rapeseed and fennel reduced the allometric coefficient.

The allometric coefficient increased significantly with increasing the salinity stress level. The lowest allometric coefficient was observed with 52.08\% increase compared to the control at $150 \mathrm{mM}$ salinity level (Tab. II). The results are consistent with those by Saglam et al. (2010) on Lentil (Lens culinaris Medik). They suggested that as the root length increased due to salinity stress, the allometric coefficient increased. Therefore, as in the present experiment, the allometric coefficient increased along with increased salinity stress levels. it is concluded that there is a higher sensitivity of the shoot compared to root under salinity conditions.

The mean comparison of interactions of hydropriming and salinity stress proved that hydropriming treatment could significantly increase allometric coefficient under increasing levels of salinity stress. The highest value of allometric coefficient was obtained at $150 \mathrm{mM}$ salinity (Fig. 4). Researchers also observed the lowest allometric coefficient in hydropriming treatment with the control salinity level.

\section{CONCLUSION}

Salinity stress as a universal threat to plant production could stop or suppress seed germination and reduce plant establishment mainly due to ionic and osmotic toxicity. Different seed priming methods have been suggested to improve seed germination, uniform emergence and strong plant 
establishment. Seed hydropriming is one of these methods. In this experiment, the effect of salinity stress and seed hydropriming on germination indices of Niger was evaluated. The results showed that the hydro prime of Niger seed resulted in the germination percentage, speed and mean germination time to be decreased significantly compared to the control treatment. The germination percentage, germination rate, the time to $50 \%$ of germination, mean germination time, mean daily germination and germination energy decreased significantly with the increasing salinity level. Salinity stress (150 mM) decreased seed vigor by $61.49 \%$, root length by $51.27 \%$, seedling length by $43.91 \%$ and increased allometric coefficient by $52.08 \%$ compared to the control. Finally, Hydropriming could positively affected the allometric coefficient and improved its value compared to the control (nonhydropriming conditions).

\section{REFERENCES}

AFLAKI, F., SEDGHI, M., PAZUKI, A. and PESSARAKLI, M. 2017. Investigation of seed germination indices for early selection of salinity tolerant genotypes: A case study in wheat. Emirates Journal of food and Agriculture, 29(3): 222-226.

BHATNAGAR, A. S. and KRISHNA, A. G. G. 2013. Effect of extraction solvent on oil and bioactive composition of commercial Indian Niger (Guizotia abyssinica (Lf) Cass.) seed. Journal of the American Oil Chemists' Society, 90(8): 1212-1203.

BIJANZADEH, E., NOSRATI, K. and EGAN, T. 2010. Influence of seed priming techniques on germination and emergence of rapeseed (Brassica napus L.). Seed Science and Technology, 38(1): 242-247.

CRAMER, G. R., ALBERICO, G. J. and SCHMIDIT, C. 1994. Salt tolerance is not associated with the sodium accumulation of two maize hybrids. Australian Journal Plant Physiology, 21: 675-692.

DAKHIL, B. B. and DENDEN, M. 2010. Salt stress induced changes in germination, sugars, starch and enzyme of carbohydrate metabolism in (Abelmoschus esculentus L.) (Moench.) seeds. African Journal of Agricultural Research, 5(12): 1412-1418.

DALEI, B. B., KHEROAR, S., MOHAPATRA, P. M., PANDA, S. and DESHMUKH, M. R. 2014. Effect of foliar sprays on seed yield and economics of Niger (Guizotia abyssinica (Lf) Cass). Journal of Agricultural science, 6(6): 143-147.

DAMALAS, C. A., KOUTROUBAS, S. D. and FOTIADIS, S. 2019. Hydro-priming effects on seed germination and field performance of faba bean in spring sowing. Agriculture, 9(9): 201.

DEMIR KAYA, M., GAMZEOKC, U. M., ATAK, A. and YAKUP, C. 2006. Seed treatments to overcome salt and drought stress during germination in sunflower (Helianthus annuus L.). European Journal Agronomy, 24(4): 291-295.

ELLIS, R. H., HONG, T. D. and ROBERTS, E. H. 1985. Handbook of seed technology for gene banks: Volume II: compendium of specific germination information and test recommendation. Rome: International Board for Plant Genetic Resources.

FAROOQ, M., BASRA, S. M. A., TABASSUM, R. and AHMED, N. 2006. Evaluation of seed vigor enhancement techniques on physiological and biochemical basis in coarse Rice (Oryza sativa L.). Seed Science and Technology, 34(3): 741-750.

FAROOQ, M., WAHID, A., AHMAD, N. and ASAD, S. A. 2010. Comparative efficacy of surface drying and re-drying seed priming in rice: changes in emergence, seedling growth and associated metabolic events. Paddy Water Environment, 8: 15-22.

GHASEMI-GOLAZANI, K., CHADORDOOZ-JEDDI, A., NASROLAHZADEH, S. and MOGHADAM, M. 2010. Effects of Hydropriming Duration on seedling vigour and Grain yield of Pinto Bean (Phaseolus vulgaris L.) Cultivars. Notulae Botanicae Horticulture Agrobotanici Cluj-Napoca, 38(1): 109-113.

HASANUZZAMAN, M. and FOTOPOULOS, V. 2019. Priming and Pretreatment of Seeds and Seedlings. Singapore: Springer Singapore.

NAIK, H. K. and DEVARAJ, V. R. 2016. Effect of salinity stress on antioxidant defense system of Niger (Guizotia abyssinica Cass.). American Journal of Plant Sciences, 7(6): 980-990.

NAIK, H. K. and VARADAHALLI, R. D. 2020. Genomic identification of salt induced microRNAs in niger (Guizotia abyssinica Cass.). Plant Gene, 23: 100242.

NAWAZ, A., FAROOQ, M., AHMAD, R., BASRA, S. M. A. and LAL, R. 2016. Seed priming improves stand establishment and productivity of no till wheat grown after direct seeded aerobic and transplanted flooded rice. European Journal of Agronomy, 76: 130-137.

NAZARBEYGI, E., LARI YAZDI, H., NASERI, R. and SOLEIMANI, R. 2011. The effects of different levels of salinity on proline and a,b,chlorophylls in canola. American-Eurasian Journal of Agricultural and Environmental Sciencei, 10(1): 70-74. 
NEMATOLLAHI, E., BANNAYAN, M. SOUHANI, A. and GHANBARI, A. 2009. Hydropriming and osmopriming effect on Cumin (Cuminum cyminum L.) seeds germination. World Academy of Science Engineering Technology, 33: 526-529.

PATIL, P. P., GHANE, S. G., BARMUKH, R. B., TEIXEIRA DA SILVA, J. A. and NIKAM, T. D. 2010 Differential response of Niger (Guizotia abyssinica Cass.) cultivars to salinity stress in relation to seed germination, oxidative stress, osmotic adjustment and antioxidant enzyme activities. Plant Stress, 4(1): 56-63.

POOJA, S. and RAJESH, K. 2015. Soil Salinity: A serious environmental issue and plant growth promoting bacteria as one of the tools for its alleviation. Saudi Journal of Biological Sciences, 22(2): 123-131.

SAGLAM, S., DAY, S., KAYA, G. and GURBUZ, A. 2010. Hydropriming increases germination of lentil (Lens culinaris Medik.) under water stress. Notulae Scienctia Biologicae, 2(2): 103-106.

STASSINOS, P. M., ROSSI, M., BORROMEO, I., CAPO, C., BENINATI, S. and FORNI, C. 2021. Enhancement of Brassica napus Tolerance to High Saline Conditions by Seed Priming. Plants, 10(2): 403.

TUNCTURK, M., TUNCTURK, R., YILDIRIM, B. and CIFTCI, V. 2011. Changes of micronutrients, dry weight and plant development in canola (Brassica napus L.) cultivars under salt stress. Africa Journal Biotechnology, 10(19): 3726-3730.

YUAN-YUAN, S., YONG-JIAN, S., MING-TIAN, W., XIANG, G., RONG, H. and JUN, M. A. 2010. Effects of seed Priming on germination and seedling growth under water stress in Rice. Acta Agronomica sinica, 36(11): 1931-1940.

Contact information

Abolrazagh Danesh Shahraki: danesh-a@sku.ac.ir (corresponding author) Afsaneh Badalzadeh: abadalzadeh65@gmail.com 